\title{
Protein A and coagulase expression in epidemic and non-epidemic Staphylococcus aureus
}

\author{
JANET I S ROBERTS, M A GASTON \\ From the Division of Hospital Infection, Central Public Health Laboratory, Colindale, London
}

SUMMARY Strains of Staphylococcus aureus were divided into groups on the basis of antimicrobial sensitivity and epidemiology and tested for protein A expression in a simple microtitre test, which detected the non-immunological binding of immunoglobulin to protein A on whole cells of $S$ aureus. Isolates of the methicillin resistant strain prevalent in south east England (EMRSA) showed a low expression of protein A compared with the other strains of methicillin resistant $S$ aureus (MRSA), other multiple resistant strains, and sensitive strains. Protein A and coagulase expression in 27 strains of MRSA from 15 countries associated with hospital outbreaks were compared with 27 strains of MRSA from 11 countries reported to be sporadic isolates. Twenty four of the 27 outbreak associated MRSA showed low expression of protein A and high expression of coagulase. Conversely, sporadic strains generally gave higher levels of protein A and a wide variety of coagulase reactions. The results suggest that many epidemic strains of MRSA may have phenotypic characteristics that distinguish them from sporadic stains.

Methicillin resistant Staphylococcus aureus (MRSA) strains currently pose a major problem in many hospitals in the United Kingdom. ${ }^{1}$ Some strains, most notably the strain of MRSA prevalent in the south east of England (EMRSA), ${ }^{2}$ spread rapidly between patients and hospital sites. ${ }^{3}$ Other strains are epidemic in other parts of the country but are not so widespread or well documented. Once established, these strains can become a long term endemic problem.

The factors that contribute to epidemic spread have not been clearly established. MRSA strains tend to be resistant to numerous broad spectrum antibiotics, ${ }^{3}$ which may contribute to their survival in the hospital environment. Only a small proportion of MRSA, however, exhibit epidemic spread which suggests that factors other than antibiotic resistance may play a part.

We have shown previously that EMRSA produces both cell bound and free coagulase and that this characteristic is not shared universally with other MRSA. ${ }^{4}$ Other work has suggested an association between coagulase and another potential virulence factor, protein A. $^{5}$ In this paper we attempted to establish a relation between these two factors in several groups of $S$ aureus.

Accepted for publication 16 April 1987

\section{Material and methods}

SOURCE OF STRAINS

United Kingdom Four groups of $S$ aureus, each comprising 10 strains, were selected on the basis of differing antibiotic resistance characters. EMRSA strains represented the range of phage types and antibiotic resistance of the strain epidemic in the south east of England; (OMRSA) other methicillin resistant $S$ aureus; (ORSA) methicillin sensitive but multiresistant $S$ aureus, and (SSA) sensitive $S$ aureus.

International MRSA were requested from all the major phage typing centres in the world, and a collection of MRSA from international sources was assembled for survey purposes. From these, 27 sporadic MRSA strains from 11 different countries and 27 outbreak associated (epidemic) MRSA strains from 15 different countries were studied. The strains were specified as epidemic or sporadic by the sending laboratory.

$S$ aureus Wood 46 (NCTC 7121), a poor protein A producer, and $S$ aureus Cowan I (NCTC 8530), a good protein A producer, were used as controls.

ESTIMATION OF PROTEIN A

Cell bound protein $A$ Staphylococci grown overnight in $3 \mathrm{ml}$ of nutrient broth at $37^{\circ} \mathrm{C}$ were centrifuged at $3000 \mathrm{rpm}$ for 15 minutes and resuspended in carbon- 
ate buffer (pH 9.6) to give an optical density of 0.2 at $600 \mathrm{~nm}$. Volumes $(50 \mu \mathrm{l})$ of doubling dilutions of the bacterial suspensions were dispensed in duplicate into flat bottomed wells in microtitre trays (Falcon) and incubated overnight at $4^{\circ} \mathrm{C}$. The plates were centrifuged at $1000 \mathrm{rpm}$ for 15 minutes and the supernatant removed. Free antigen binding sites were blocked for 30 minutes with a solution of $1 \%(w / v)$ skimmed milk and $10 \mathrm{mmol}$ glycylglycine in phosphate buffered saline (PBS). The plates were washed three times in PBS $+0.05 \%$ Tween 20 . Fifty $\mu 1$ of a $1 / 200$ dilution of peroxidase conjugated rabbit immunoglobulins (Dako) in PBS $+0.05 \%$ Tween 20 were added to each well. The plates were incubated at $37^{\circ} \mathrm{C}$ for one hour and then washed five times as above. Substrate $(50 \mu \mathrm{l})$ was added to each well and the reaction was stopped after 10 minutes by the addition of $12.5 \%$ (v/v) sulphuric acid. The substrate, a solution of $24.3 \mathrm{ml} 0 \cdot 1 \mathrm{M}$ citric acid, $25.7 \mathrm{ml} 0.2 \mathrm{M}$ sodium hydrogen phosphate, $50 \mathrm{ml}$ deionised water, $34 \mathrm{mg}$ orthophenylenediamine and $40 \mu \mathrm{l}$ hydrogen peroxide, was prepared fresh as required. Absorbance was measured at $492 \mathrm{~nm}$.

The titre of the test strain was defined as the highest dilution that gave an absorbance of greater than $0 \cdot 1$. The relative antibody binding capacity (RABC) for cell bound protein $\mathrm{A}$ was defined as the ratio between the titre of the test strain and the control strain ST84/6195 (EMRSA) which was included in each plate.

Extracellular protein A Microtitre wells were coated with the supernatant recovered by centrifugation of a $37^{\circ} \mathrm{C}$ overnight nutrient broth culture of $S$ aureus. Doubling dilutions $(50 \mu \mathrm{l})$ of the supernatant in carbonate buffer were dispensed into duplicate microtitre wells and the plates were incubated overnight at $4{ }^{\circ} \mathrm{C} \stackrel{\text {. }}{5}$ Protein A was determined as before, but the controf. strain ST84/5889 (SSA) was used because the EM $\overrightarrow{=}$ RSA control expressed very low levels of extracellular protein A.

The slide coagulase test was performed on the in $\frac{\bar{\sigma}}{\bar{s}}$ ternational epidemic and non-epidemic strains with human plasma diluted 1/10 in nutrient broth. Each test was carried out in duplicate and the results weres scored according to the system previously described. 4

The $\chi^{2}$ test was used to assess the significance of the combined results of the protein $A$ and coagulase de $\vec{\omega}$ terminations for the international strains.

\section{Results}

\section{UNITED KINGDOM STRAINS}

Cell bound protein $A$ Table 1 shows the RABC of cell bound protein A for the four groups of United Kingdom strains. EMRSA produced less cell bound protein A than most of the other United Kingdom strains, irrespective of their antibiotic resistance. On EMRSA isolate expressed a particularly low level of bound protein $A$. The average RABC of the cello bound protein $\mathrm{A}$ was 2.23 for all the strains of EMRSA tested and 11.5 for the other three groups. One strain from the ORSA group and one from the SSA group expressed lower levels than EMRSA Most of the other strains had an RABC of at least 8 .

The cell bound protein A content of strain Cowano I was 16 times greater than that for the EMRSA con은 trol, which gave values similar to the Wood 46 contro $\overrightarrow{\vec{B}}$ strain.

Extracellular protein $A$ Table 2 shows the RABC of the four groups of strains. EMRSA released less ex

Table 1 Cell bound protein A expression in United Kingdom strains of $S$ aureus of differing antibiotic resistance characters

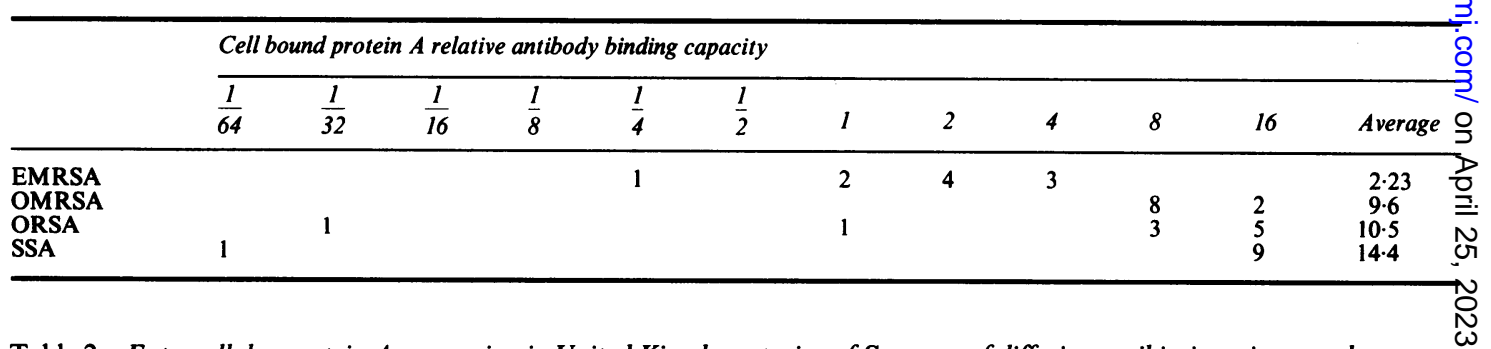

Table 2 Extracellular protein A expression in United Kingdom strains of $S$ aureus of differing antibiotic resistance characters ${ }_{\sigma}$

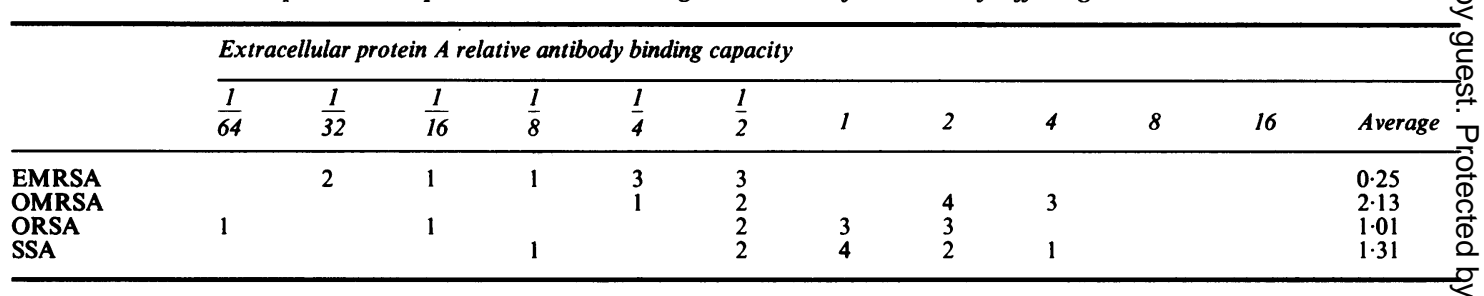


tracellular protein A than the other United Kingdom $S$ aureus tested. The EMRSA gave an average RABC of 0.25 compared with 1.48 for all the other three groups combined. These groups exhibited a wider range of extracellular protein A than cell bound protein A. The strains in the ORSA and SSA groups, which showed low levels of cell bound protein A, also expressed low levels of extracellular protein $A$. The RABC of the Cowan I and Wood 46 strains were 2 and 4 , respectively.

INTERNATIONAL MRSA STRAINS

Cell bound protein $A$ The figure shows the RABC for cell bound protein $A$. The epidemic strains ex-

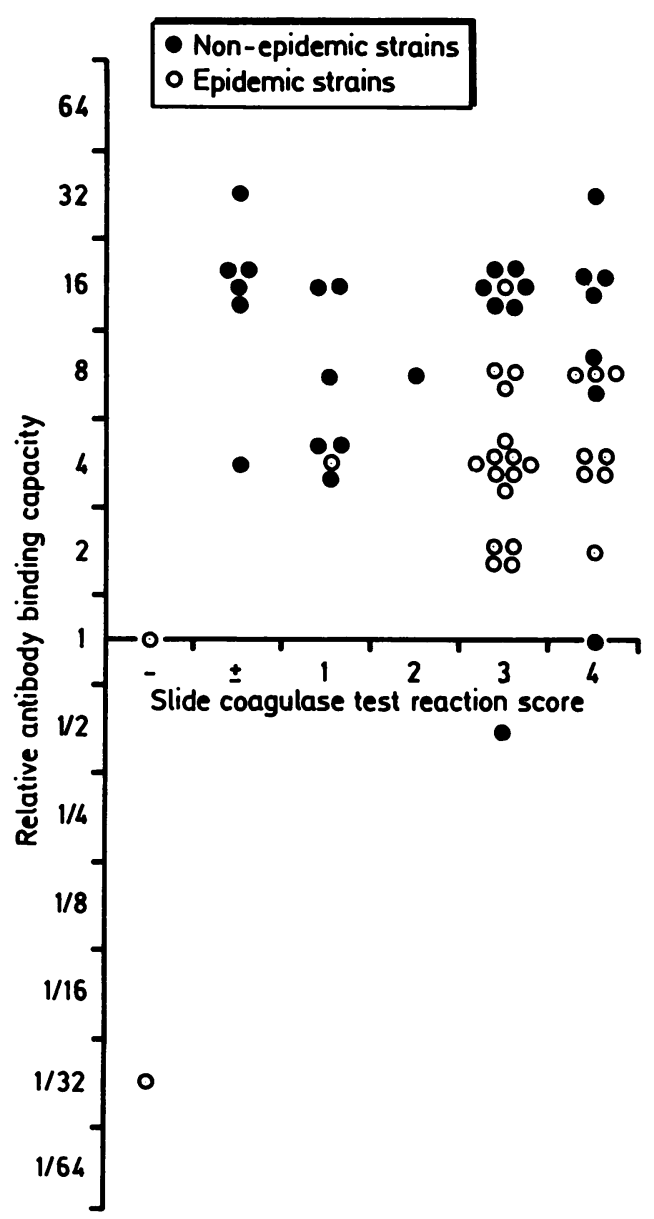

Figure Cell band protein $A$ and coagulase in international strains of MRSA. pressed low levels of cell bound protein A, comparable with the levels observed in EMRSA. The non-epidemic strains generally exhibited high levels of protein A similar to most of the other United Kingdom $S$ aureus tested.

Slide coagulase test Twenty four of $27(89 \%)$ of the epidemic strains gave strong positive results in the slide coagulase test (figure). A wider range of results were shown by the non-epidemic strains, $48 \%$ of which gave $+/-, 1+$, or $2+$ reactions. Previously we reported that EMRSA gave strong positive results in the slide coagulase test but that other MRSA often gave weak results. ${ }^{4}$

A plot of cell bound protein A and strength of reaction in the slide coagulase test for each strain showed a cluster of epidemic strains with low cell bound protein $\mathrm{A}$ but strong slide coagulase reaction (figure). A vertical line at the $3+$ reaction in the slide coagulase test score and a horizontal line at the RABC value of 4 divided the plot into strong and weak reactions for both tests. There was significant clustering of the epidemic strains in the quadrant representing strong coagulase but poor protein A production $\left(\chi^{2}=22 \cdot 3\right.$, $3 \mathrm{df}, \mathrm{p}=0.001$ ).

\section{Discussion}

Some strains of MRSA give rise to outbreaks producing infection or colonisation, or both, but others do not. In terms of patient management it would be extremely useful to be able to distinguish strains that are potentially epidemic from non-epidemic or sporadic strains. The results of our study suggest that epidemic strains have properties which distinguish them from sporadic strains. The characters observed here, low levels of protein A and high levels of coagulase, are not absolutely definitive but may indicate potentially epidemic strains.

A variety of external factors influence protein A production $^{6-9}$ and conditions in vivo may produce different results than in vitro situation studied here. No specific virulence factor has been attributed to pathogenic $S$ aureus, and protein A seems to be only one of the many possible contributory factors. It has been suggested that deficiencies in protein $A$, or clumping factor, or both, have been responsible for containment of an MRSA strain within a unit. ${ }^{10} \mathrm{Our}$ results would seem to suggest otherwise, as EMRSA and other epidemic strains generally produce less protein A than the non-epidemic strains tested. Protein A production does not seem to be associated with antibiotic resistance. Methicillin resistance per se is not indicative of a lack of, or poor, protein A production, as has been previously suggested. ${ }^{11}$

EMRSA possesses properties distinct from other non-outbreak associated strains of differing antibiotic 
resistances within the United Kingdom but comparable with other epidemic strains from around the world. EMRSA and the international outbreak associated strains studied both expressed low levels of protein $A$ and strong slide coagulase reactions. Two of the international sporadic strains gave similar results and were subsequently found to be similar to EMRSA in their antibiotic resistance profiles and phage types.

Initially we restricted our study to methicillin resistant strains in which the resistance provides a useful epidemiological marker. It will be necessary to extend the study to include methicillin sensitive epidemic and sporadic strains to determine whether this relation between protein $A$ and coagulase applies to other epidemic strains.

\section{References}

1 Casewell MW. Epidemiology and control of the "modern" methicillin-resistant Staphylococcus aureus. J Hosp Infect 1986;7(suppl A):1-11.

2 Marples RR, Richardson JF, de Saxe MJ. Bacteriological characters of strains of Staphylococcus aureus submitted to a reference laboratory related to methicillin resistance. J Hyg (Camb) 1986;96:217-23.

3 Workshop on methicillin-resistant Staphylococcus aureus held at the headquarters of the Public Health Laboratory Service on 8 January 1985. J Hosp Infect 1985;6:342-8.
4 Dickson JIS, Marples RR. Coagulase production by strains of Staphylococcus aureus of differing resistance characters: a음 comparison of two traditional methods with a latex agglutination system detecting both clumping factor and protein $A . \overrightarrow{\bar{F}}$ J Clin Pathol 1986;39:371-5.

5 Forsgren A. Significance of protein A production by staphylo음 cocci. Infect Immun 1970;2:672-3.

6 Gemmel CG, O'Dowd A. Regulation of protein A biosynthesis in Staphylococcus aureus by certain antibiotics: its effect on $\vec{D}$ phagocytosis by leucocytes. J Antimicrob Chemother 1983;으 12:587-97.

7 Milatovic D. Effect of subinhibitory antibiotic concentrations on the phagocytosis of Staphylococcus aureus. Eur J Clin Micro-. biol 1982;1:97-101.

8 Milatovic D, Braveny I, Verhoef J. Clindamycin enhances op- $\vec{\omega}$ sonization of Staphylococcus aureus. Antimicrob Agents Chemother 1983;24:413-7.

9 Root RK, Isturiz R, Molavi A, Metcalf JA, Malech HL. Interaction between antibodies and human neutrophils in the killing 0 of staphylococci: studies with normal and cytochalasin B-O treated cells. J Clin Invest 1981;67:247-59.

10 Lacey RW, Barr KW, Barr VE, Inglis TJ. Properties of methicillin-resistant Staphylococcus aureus colonizing patientso in a burns unit. $J$ Hosp Infect 1986;7:137-48.

11 Lind I. Correlation between the occurrence of protein $\mathbf{A}$ and some other properties in Staphylococcus aureus. Acta Path Microbiol Scand 1972 (Section B);80:702-8.

Requests for reprints to: Dr MA Gaston, Central Publiẹ Health Laboratory, Division of Hospital Infection, 61 Colindale Avenue, London NW9 5HT, England. 